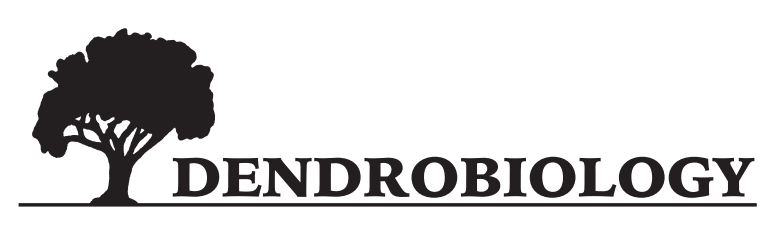

2018, vol. 80, 37-47

http://dx.doi.org/10.12657/denbio.080.004

\author{
Zdeněk Špišek, Andrea Uherková, Marek Svitok, Radim J. Vašut*
}

\title{
Sorbus domestica L. at its northern Pannonian distribution limits: distribution of individuals, fruit shapes and dendrometric characteristics
}

Received: 14 November 2017; Accepted: 14 June 2018

\begin{abstract}
Fruit species play an important role in human nutrition. For this reason, they have been cultivated for millennia. Their cultivation and domestication have impacted species distribution considerably. Wild relatives of such species are often rare in Europe and are threatened by loss of habitat and landscape fragmentation. Knowledge of the distribution and biological characteristics of populations is crucial for further species conservation. We investigated the detailed distribution of the service tree (Sorbus domestica L.) in the White Carpathians, which represents the largest occurrence of the species at its northern distribution limit in Central Europe. We recorded 473 individuals in the studied region, compared their habitats, fruit type, dendrometric characteristics and the climate conditions at the sites. Our data suggest that the occurrence of the species is most likely of human origin and that the vast majority of trees grow in orchards, vineyards or on open landscape $(72.7 \%)$. The comparison of fruit types has not revealed a strong pattern, although fruit types have apparently been selected by growers. Although most documented trees probably have an anthropogenic origin, they represent an important element in the landscape of Central Europe that requires protection.
\end{abstract}

Keywords: chorology, archaeophyte, fruit shape, dendrometric data

Addresses: Z. Špíšek, R. J. Vašut, Department of Botany, Faculty of Science, Palacký University in Olomouc, Olomouc, Czechia, e-mail: radim.vasut@upol.cz; zdenek.spisek@upol.cz

A. Uherková, Department of Landscape Planning and Design, Faculty of Ecology and Environmental Studies, Technical University in Zvolen, Zvolen, Slovakia

M. Svitok, Department of Biology and General Ecology, Faculty of Ecology and Environmental Sciences, Technical University in Zvolen, Zvolen, Slovakia

Radim J. Vašut, Department of Botany, Faculty of Science, Palacký University in Olomouc, Šlechtitelů 27,

78371 Olomouc, Czechia; e-mail: radim.vasut@upol.cz

${ }^{*}$ Corresponding author

\section{Introduction}

Collecting fruits of wild plants has played an important role in the livelihoods of people since the Palaeolithic era, long before plant domestication
(Harlan, 1975). The domestication of the tree fruit species started several millennia after the domestication of cereals (Janick, 2005), overlapping with the early cultivation of wild fruit species. Fruits were an important source of nutrition and energy, especially 
during famine or migrations (Goldschmidt, 2013). The development of pomiculture progressed considerably during the late Neolithic and Bronze Ages between 6000 and $3000 \mathrm{BC}$, since the Mediterranean fruits were cultivated (Zohary \& Spiegel-Roy, 1975; Janick, 2005). The vast majority of fruit trees originated in the Middle East (Tischler, 1965) and later spread to Europe during the agricultural expansion or later with ancient Greek or Roman civilisations. Evidence of ancient use of fruits is provided by art, wherein depicting fruit motifs was common in ancient civilizations such as in the Sumerians, Egyptians, and Mesopotamians; the oldest pictorial evidence of fruit growing comes from recent Iraq dating approximately 3000 BC (Janick, 2005). The fruit-species cultivation and domestication shaped not only their species genomes via selection and hybridization (e.g., in Malus; Velasco et al., 2010; Nikiforova et al., 2013), but also impacted the species distribution. Distribution of woody fruit species and their wild relatives in Europe usually reflects human influence. Specifically, species such as Prunus cerasifera, Malus domestica or Pyrus communis occur frequently on ruderal or semi-ruderal sites in cultural landscape, whereas species such as Pyrus pyraster, Malus sylvestris, Prunus brigantina and other relatives of domesticated fruit species have either geographically limited or scarce distribution in their natural biotopes due to their disappearance and landscape fragmentation. Sorbus domestica (a service tree) is a species that has been cultivated for fruit for millennia and has a scarce distribution in both cultural landscape and natural biotopes.

The broad genus Sorbus belongs to the apple tribe (Maleae, syn. Pyreae) of the Rosaceae family, which is known for its young evolutionary origin and reticulate evolution (Robertson et al., 1991; Campbell et al., 2007; Potter et al., 2007). The genus Sorbus includes approximately 127 species in Europe and North Africa and approximately 250 species widespread in the northern hemisphere (Aldasoro et al., 2004). Moreover, the genus Sorbus is paraphyletic with complex evolutionary and controversial taxonomy (Robertson et al., 1991; Campbell et al., 2007; Potter et al., 2007), and the species traditionally classified in this genus are split into five genera (Sorbus s.str., Aria, Chamaemespilus, Torminaria and Cormus; Robertson et al., 1991; McAllister, 2005). The apple tribe genera easily hybridize among themselves (including Sorbus s.l.) except a few taxa (such as S. domestica), which do not hybridize even with the closest relatives (Robertson et al., 1991).

Sorbus domestica can be grouped in the monotypic genus Cormus if the phylogenetic approach is applied on the genus Sorbus s.l. Unlike other Sorbus s.l. species, $S$. domestica is taxonomically homogeneous, not forming any hybrids or apomictic accessions (Kárpáti, 1960; Warburg \& Kárpáti, 1968; Scheller et al., 1979; Nelson-Jones et al., 2002). Today, the species
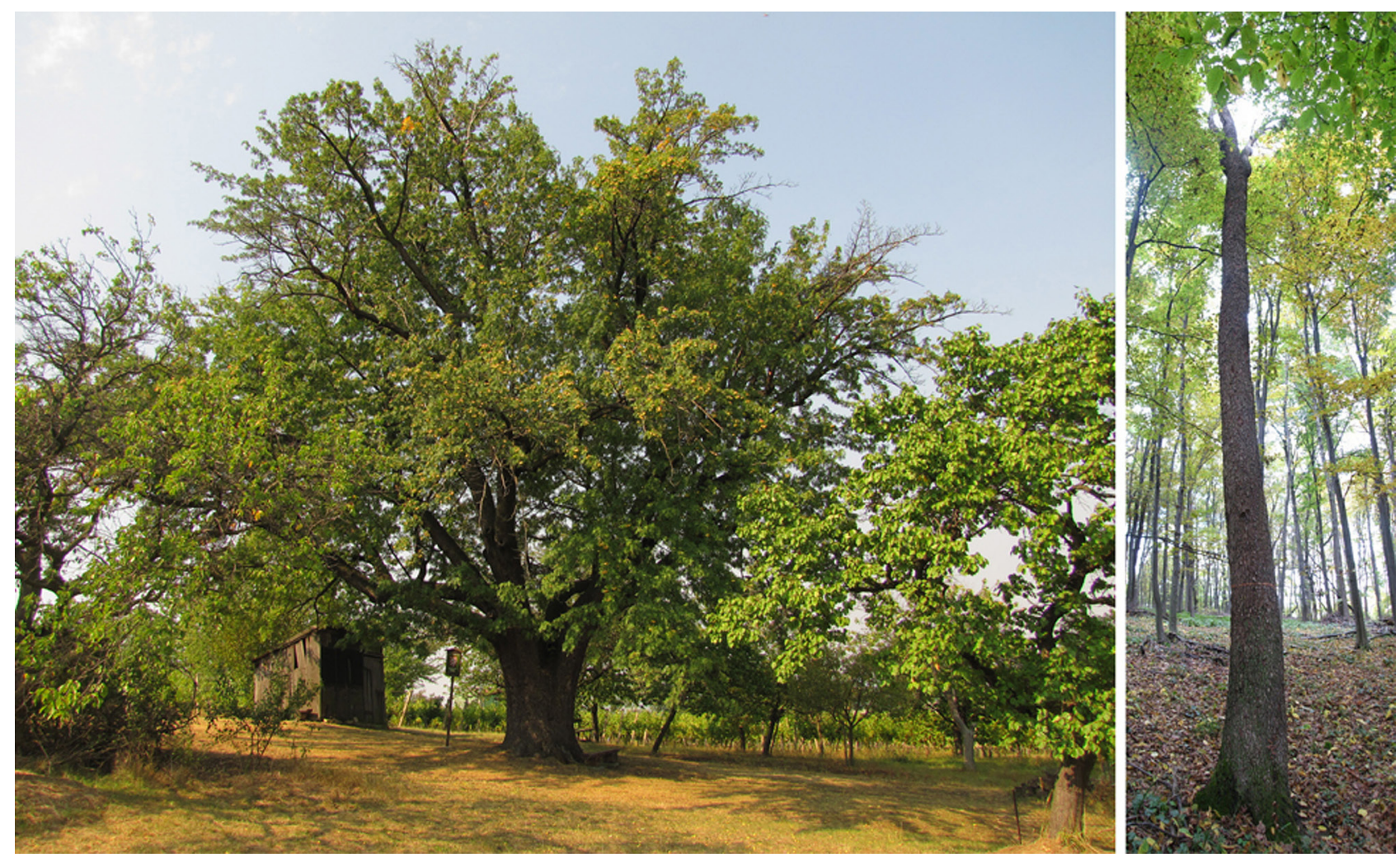

Fig. 1. Habitus of the Sorbus domestica tree. Left: old tree with broad tree crown growing in the garden (orchard). Right: young tree with the high trunk and absent branches growing in forest 
is rare in Europe, with the highest frequency of occurrence in the Mediterranean Europe (Balkans, Italy, southern France) and a scattered distribution across Central and Western Europe, extending to Crimea in Ukraine, eastwards, and Northern Africa, southwards (Bignami \& Cammilli, 1998; Moinet, 2009; Drvodelić et al., 2015; George et al., 2015; Poljak et al., 2015). It has a two-millennia-long tradition of cultivation in the Mediterranean region dating back to ancient Rome (Brütsch \& Rotach, 1993), with the oldest record from Theophrastos (371-287 BC) in ancient Greece (Kausch-Blecken von Schmeling, 2000). The service tree is tolerant to xerothermic climate conditions and water deficit (Rotach, 2003; Pagan \& Paganová, 2000; Paganová, 2008; Paganová et al., 2015). Fruits are used in pharmacology, folk medicine, fresh consumption and processing or honey and cider production (Kausch-Blecken von Schmeling, 2000; Végvári, 2000; Termentzi et al., 2006).

Species occurrence in Central Europe (including Slovakia, Austria and Czechia) is divided into several discontinued areas and is a northern limit of its distribution area in this part of Europe (Enescu et al., 2016). In Czechia, it grows only in two large metapopulations in Central Bohemia (Bohemian Central Uplands) and in the south-eastern Moravia, which shares a border with Slovakia (the White Carpathians) (Kaplan et al., 2016). Several scattered and small populations are found in the other regions of Moravia (Úradníček et al., 2009). The occurrence in the White Carpathians extends across the border with Slovakia and continues across the Western Carpathian Mountains. In Slovakia, they occur in the warmer foothills of the Carpathians (especially the White Carpathians, Small Carpathians, Štiavnické Vrchy mountains, Strážovské Vrchy mountains, Tokai region - Miko \& Gažo, 2004; Paganová et al., 2015)

The aim of this study was to evaluate the distribution of the true service tree in the White Carpathians, specifically in the region having the largest occurrence in Central Europe. Further, we aimed to explain the role of humans and their impact on the species distribution here based on regional climate, ecology and dendrometric parameters. We researched whether there is pattern in fruit shape indicating selection by humans for attractive fruit shapes, and whether the biotope and dendrometric characteristics can explain the origin of individuals in the studied region.

\section{Materials and Methods}

\section{Study site}

The study area is located in the White Carpathians, which is the westernmost part of the Western Carpathian Mountains. Its unique nature and landscape are protected as the Protected Landscape Area (PLA) and Biosphere Reserve. Characteristic landscape of the White Carpathians comprises species-rich semi-dry meadows (Bromion erecti alliance) often with scattered trees, occurring mainly in the south-western part, extensive areas of beech forests in the central and north-eastern part, and oak-hornbeam forests in the south-western part (Otýpková et al., 2011). The lowland and low situated slopes have a warm climate, slopes of upper locations have mild warm climate, and only top part of the White Carpathians has a mild cold climate. The mean annual temperatures fluctuate from 6.6 to $8.7^{\circ} \mathrm{C}$, and the annual precipitation ranges from 665 to $835 \mathrm{~mm}$ (Lapin et al., 2002; Tolasz et al., 2007).

In the studied area, S. domestica occurrences in the White Carpathians are known in two ecologically/ phytogeographically contrasting regions: the thermophilous steppes and the mesophilous forests. On the White Carpathians slopes of the range the species has diffused distribution and can be found mainly in agricultural landscape, affected by man for centuries (Tetera et al., 2006), and usually grows solitary or in small groups, as is typical for this species (Mikic et al., 2008).

\section{Data collection and analyses}

The study was carried out during the vegetation period from 2008 through 2016. The study of this tree was focused within the PLA, including the individuals situated out of the border. The field research included both the residential and rural landscape as well forest and non-forest biotopes. The localities of the field research include the whole area of the White Carpathians. The localization of individuals was recorded by GPS GARMIN eTrex 10. The total of 473 individuals was determined and measured. Fruits were collected from various positions throughout the area from August through October during all mapping seasons. The circumference of each sampled tree was measured with a tape-measure to calculate the $\mathrm{DBH}$ (diameter at breast height) at $1.3 \mathrm{~m}$ above the ground. Tree height was measured by a Suunto PM-5/360 PC hypsometer. Since the species occurs in different types of biotopes, the localities with $S$. domestica occurrence were selected based on the field work and the presence of important landscape elements and divided into six categories: open landscape (124 individuals, $26.3 \%$ ), orchard/garden (178 individuals, $37.7 \%$ ), forest exterior (61 individuals, $12.9 \%$ ), forest interior (24 individuals, $5.1 \%$ ), balk (44 individuals, 9.3\%) and vineyard (42 individuals, $8.7 \%)$.

Fruits were classified into six categories based on the shape (according to Bignami \& Cammilli, 1998): flattened, spheroidal, pyriform, conical, egg-shaped 

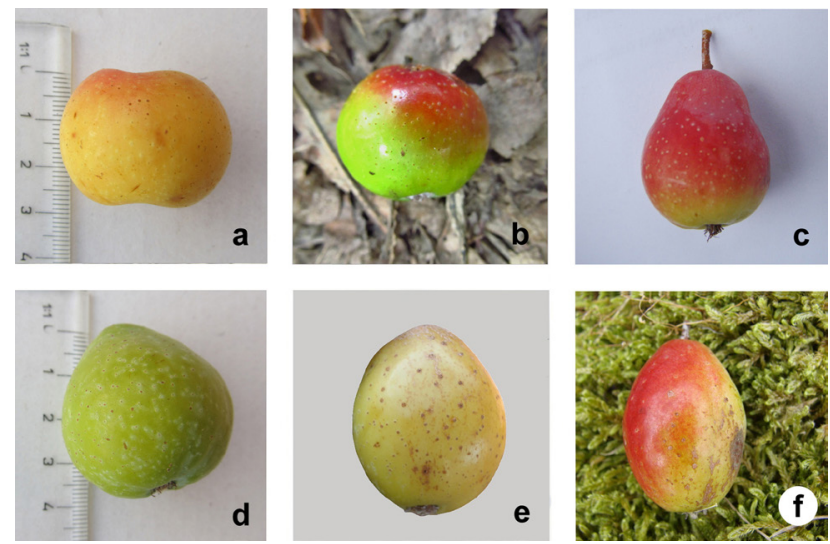

Fig. 2. Fruit shapes of Sorbus domestica in the White Carpathians (according to Bignami \& Cammilli, 1998): a) flattened, b) spheroidal, c) pyriform, d) conical, e) eggshaped, f) elliptical

and elliptical (see Fig. 2). The shape was determined on fruits randomly collected on all parts of the tree crown prior to full ripening (i.e. before turning brown and soft). If the fruit shape was variable within individual, it was determined as an average of the prevailing shape. The size of the fruit was not considered because the variability in size is influenced by abiotic factors (see e.g. Miletić \& Paunović, 2012).
The map data were prepared and the orientation slopes were processed in Geographic Information Systems - Arc View version 3.1. The maps basis was with an obtained digital geographic database ArcČR ${ }^{\circledR} 500$ v 3.3 for climatic regions (Květoň \& Voženílek, 2011). The analysis comprising the altitude and orientation slopes was made in NCSS 9 Statistical Software (2013, Kaysville, UT, USA). Analysis of covariance (ANCOVA) was used to investigate the relationships between height, $\mathrm{DBH}$ and the location of service trees. Before analysis, the data on height and DBH were log transformed to linearize data and stabilize variances. The relationship between fruit shape and tree location was fitted using a multinomial model via neural networks (Venables \& Ripley, 2002). The analyses were performed in $\mathrm{R}$ (version 3.2.3; R Core Team, 2015).

\section{Results}

\section{Geographical distribution of service trees}

During the study, 473 individuals of the service tree at the Czech and Slovak sites of the White

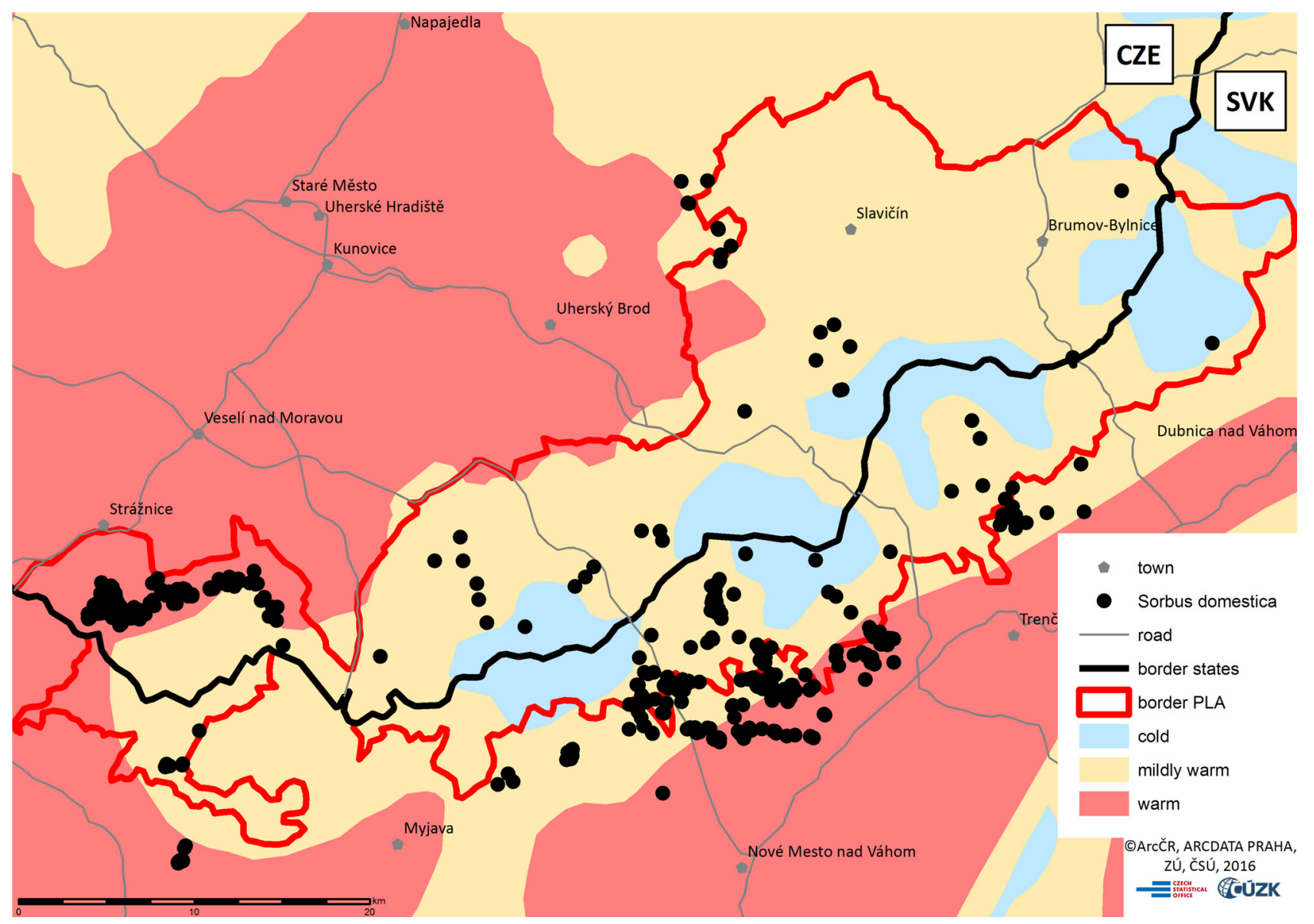

Fig. 3. Climate regions and Sorbus domestica distribution in the White Carpathians and their surroundings 


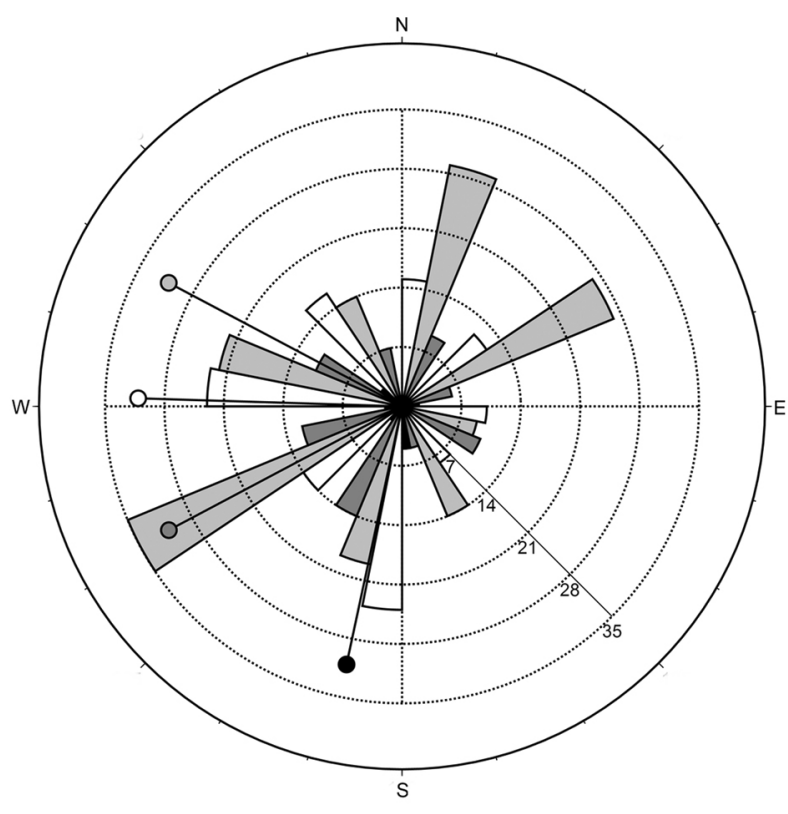

Fig. 4. Comparison of altitude and orientation slopes of $S$. domestica. Altitudinal levels: $\square$ 200-299 m a.s.l., ㅁ 300-

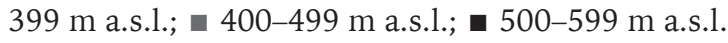

Carpathians were documented. Their distribution is plotted in Fig. 3.

The individuals of $S$. domestica forming the largest occurrence were located in the South Moravian region at the Czech site as well as at the foothills of the middle part of the White Carpathians at the Slovak site. According to the climate map, the individuals grow mainly in the mildly warm and moist climate region $(48 \%)$ and in the warm, very dry or mildly wet regions $(51 \%)$. Only $1 \%$ of the recorded trees were situated in the cold region. The "hot spot" of the service tree occurrence is in the S-W at the Czech site of the mountain range, at the Žerotín hill, which lies in the in warm, very dry or mildly wet region; $31.6 \%$ of all recorded individuals grow in this region.

Most localities (44.5\%) were on altitude 200-299 $\mathrm{m}$ a.s.l. (Fig. 4). The most frequent slope exposure in this altitude is west, but many trees grow on south slopes. The second most frequented category of the localities (32.1\%) is at the altitude $300-399 \mathrm{~m}$ a.s.l. with the most frequent slope exposure towards the west and north-west, but trees often grow on southwest and northeast slopes. Less frequent occurrences (19.5\%) were on the altitude 400-499 m a.s.l. with the most frequent slope exposure towards the southwest exposure. Only small part of localities (3.9\%) are situated on the altitude 500-599 m a.s.l. and the only single individual was found at an altitude higher than $600 \mathrm{~m}$ a.s.l., on the Kykula hill (Chocholná-Velčice village in Slovakia, $662 \mathrm{~m}$ a.s.l.), with the southward exposure.

\section{Distribution of fruit types}

The site of service trees significantly affects the shape of fruits $\left(\chi_{(25)}^{2}=40.8, \mathrm{p}=0.024\right)$. The greatest diversity of fruit shapes was recorded in the forest interior, where all types were discovered (Fig. 5). Flattened fruits were not recorded in the vineyards and balks while elliptical fruits were restricted to vineyards, forests and orchards/gardens.

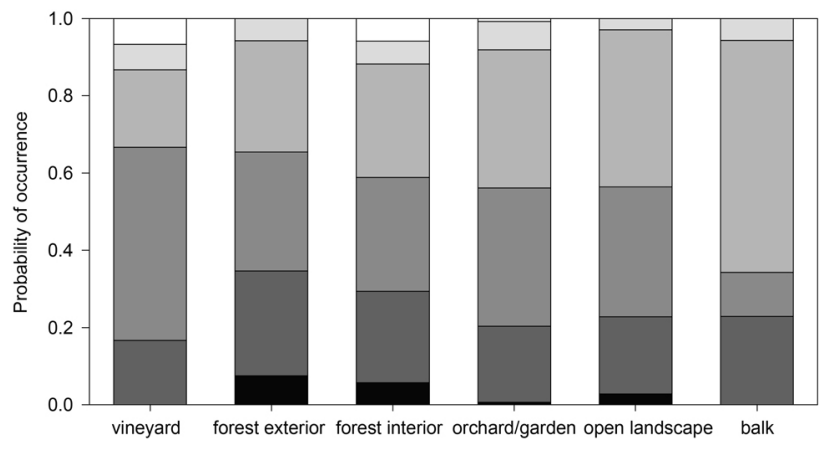

Fig. 5. Fruit shape types of S. domestica in different site types. The highest density of fruit shape types was in the region of the Žerotín hill (near Strážnice). The most frequent shapes were the conical $(37.1 \%)$, pyriform $(32.7 \%)$ and spheroidal $(21.1 \%)$. The other types of fruit shapes were rare. Fruit shapes: a flattened; - spheroidal; n pyriform; | conical; n egg-shaped; $\square$ elliptical

\section{Dendrometric characteristics}

The average height of individuals was $11.5 \mathrm{~m}$ and the tallest tree was found in the forest interior (approximately $25 \mathrm{~m}$ ). DBH of the investigated individuals ranged from 0.15 up to $1.45 \mathrm{~m}$. More than a half of the individuals fell within the DBH range 26-75 $\mathrm{cm}$. Some very large trees of $S$. domestica with the DBH more than $1 \mathrm{~m}(5.9 \%)$ were present in this area, and many were still fertile. Supposedly young individuals (DBH $<25 \mathrm{~cm}$ ) were less frequent $(13.2 \%)$.

ANCOVA revealed a significant positive relationship between the $\mathrm{DBH}$ and height of service trees $(\mathrm{F}(1,455)=142.82, \mathrm{p}<0.001)$, and this effect was independent of the sampling location (location $\times$ height: $F(5,455)=1.83, p=0.106)$, i.e., the rate of height increase with tree DBH was similar at each location with minor exception of forest interiors (Fig. 6). However, location significantly influenced the height of trees $(\mathrm{F}(5,455)=9.00, \mathrm{p}<0.001)$. The ANCOVA model explained $29 \%$ of the variability in tree height.

There was a considerable variation in dendrometric parameters among localities. Notably, shape (DBH-to-height ratio) of the trees growing in forest interiors was significantly different from the other 


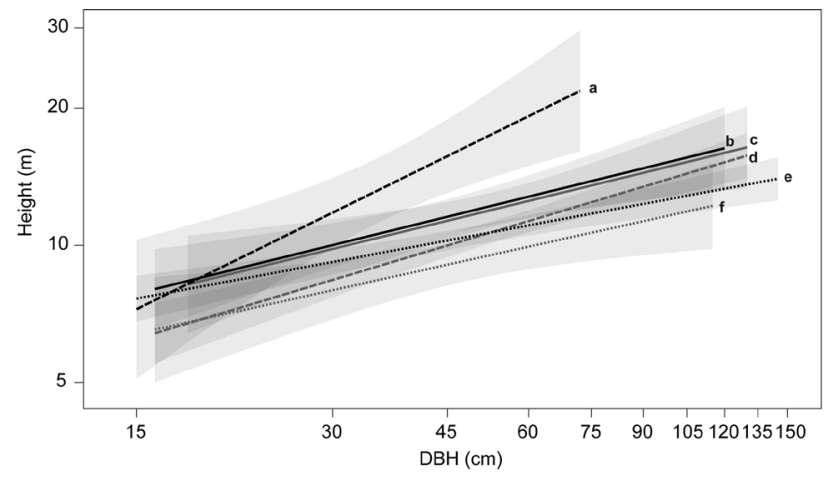

Fig. 6. Results of ANCOVA showing DBH-height relationships for service trees growing at six different locations. Least-squares regression lines are displayed along with $95 \%$ confidence intervals (grey area). Note the log-scaling of axes

Location: a. forest interior; b. balk; c. forest exterior; d. open landscape; e. orchard or garden; f. vineyard

locations (Fig. 7). According to the evaluated DBH categories and different localities (Fig. 7), there was a tendency of increase in quantity of trees with an increase in the DBH category in the open landscape. The same pattern was found for individuals growing in the forest exterior. The largest individuals, with a DBH greater than $101 \mathrm{~cm}$, grew mainly in the open landscape and in orchards/gardens $(37.5 \%$ in both categories); $17.9 \%$ of these largest trees were growing in the forest edge, while only a few were found in the forest interior or in the balks.

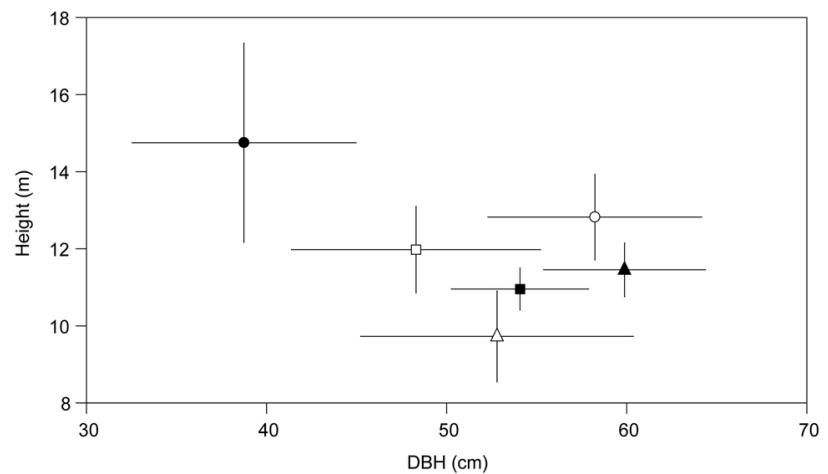

Fig. 7. The effect of tree location on the DBH. Circles represent mean values, and error bars are 95\% confidence intervals. Location: balk (empty square); forest exterior (empty circle); forest interior (full circle); open landscape (full triangle); orchard/garden (full square); vineyard (empty triangle)

\section{Discussion}

Sorbus domestica mainly grow in warm and dry climatic regions $(51 \%)$ or mildly warm and moist climatic regions (48\%) with most occurrences at the colline altitude between 200 and 399 m a.s.l. Notably, occurrences of the northern slopes of the White
Carpathians belong to a warmer climatic region than those ones in the southern slopes of the studied hills. From a phytogeographic point of view, at least some occurrences (especially in the dry climatic regions) might resemble the autochthonous population; however, our data on the distribution patterns and the morphological data primarily (discussed below) suggest an anthropogenic origin of studied populations.

\section{Service tree in the White Carpathians}

The occurrence in the White Carpathians represents the northern limit of the species distribution area in this part of Europe (Kausch-Blecken von Schmeling, 2000). Although the populations are small and scattered across the studied region, they represent the largest and the most vital metapopulation of the service tree in Central Europe. This service tree prefers warm or mild warm climate regions, and a limiting factor for its distribution is spring temperature: late frosts in May (during blooming) can seriously hamper the reproduction ability of the species.

In the White Carpathians, the service trees prefer areas with altitudes between 200 and 600 metres above sea level, and only $23.4 \%$ of the $S$. domestica individuals grow in the altitude between 400 and $599 \mathrm{~m}$ a.s.l. These data concur with its documented requirements for the dry and xerothermic biotopes. Approximately $90 \%$ of the formerly researched $S$. domestica occurrences (Paganová, 2008) are located at a similar altitude, but those in more continental climate grow up to $400 \mathrm{~m}$ a.s.l. In the northernmost part of its natural distribution area in Saxony-Anhalt (Germany), the service tree grows at low altitudes between 140 and $300 \mathrm{~m}$ a.s.l. In the southern parts of Europe, it grows in higher altitudes, such as in Switzerland (between 380 and $700 \mathrm{~m}$ a.s.l.; Kamm et al., 2009), Bavaria near Münich (up to $800 \mathrm{~m}$ a.s.l.) or the Balkans (between 600 and $900 \mathrm{~m}$ a.s.l.). In the warmest regions of the Mediterranean, it has been documented in the higher mountainous altitudinal level, specifically $1350 \mathrm{~m}$ a.s.l. (Kausch-Blecken von Schmeling, 2000) or $1400 \mathrm{~m}$ a.s.l. in Spain (Mikic et al.,, 2008). In the White Carpathians individuals of $S$. domestica are scattered as is typical for this species, with the densest occurrence in warm climate regions. The most distinct population grows in the larger area of the Žerotín hill (nearly $32 \%$ of documented individuals). The hill slopes host fragments of the natural thermophilous oak forests of Quercus pubescens (Jongepierová, 2008; Chytrý et al., 2010), but its foothills are covered with centuries-old vineyards. Due to the large number of service tree individuals and natural characters of the forests here, the autochthonous origin for the populations in this area was hypothesized; however, our data suggest 
an anthropogenic origin. A key argument for the non-natural origin of the Žerotín population is the spatial distribution. Many individuals grow in an agricultural landscape, particularly as single individuals or groups of a few plants between the fields and vineyards. Occurrences in the forest biotopes here are scarce and probably represent a spontaneous dispersion from the agricultural landscape than a relic occurrence of former natural populations.

The juice from unripe service tree fruits is used for wine clarification and stabilization (Hrdoušek et al., 2014). The vine-planting tradition in the Žerotín hill has been known since the $15^{\text {th }}$ century. The occurrence here follows its historical use as a fruit tree, mainly cultivated in orchards, gardens or between vineyards. The occurrence in the Žerotín hill illustrates the overall distribution in the area. The Czech populations, $8.7 \%$ in the vineyards and even more in gardens and orchards $(37.7 \%)$ were compared. The service tree in the studied agricultural landscape usually grows with other fruit trees, which strongly supports its non-natural origin. Similarly, a high proportion of solitary single individuals $(26.3 \%)$ growing in the meadows, between fields, confirms the anthropogenic origin of this important landmark tree.

The occurrence of trees in the agricultural landscape alone is not evidence for the non-natural origin of trees. The analysis of the service tree population distribution in the Tokai hills in Hungary revealed that very old trees scattered in the agricultural landscape represent a relic occurrence of trees (Rapaics, 1940; Nyári, 2010). During the transformation of the forested landscape to the agricultural landscape, the $S$. domestica trees were retained on sites. Another explanation of natural origin is provided by the local tradition documented, for instance, by Holuby (1888), because people used to plant seedlings or root suckers, from woods (natural sites), in their gardens. This was documented by the local people of the Maršov, Hroznová Lhota villages (Hrdoušek et al., 2014). However, these kinds of natural occurrences do not fit into the spatial patterns of the studied local populations, as $S$. domestica is currently missing in natural oak forests in the whole studied area. Analyses of the morphological characteristics of individuals in the studied populations further support the human origin of cultivated trees in the studied region.

\section{Morphological characteristics of studied individuals}

The fruit shape types were compared according to Bignami and Cammilli (1998) to analyse phenotype variation within and among studied individuals, although some authors (Miletić \& Paunović, 2012) distinguish only two shape types - apple-shaped (62.4\%) versus pear-shaped $(37.6 \%)$. When we focus on the distribution of different fruit shape types in all areas (Fig. 8), there was no obvious pattern, although there is a presumption that individuals very close to each other have the same fruit shape type. Trees with elliptical fruits individuals were found to be very rare in the studied area $(1.1 \%$ out of all known samples). These phenotypes probably originated from the spontaneous dispersion and their low frequency is probably a result of negative selection by a man. Another factor supporting the non-natural origin of studied localities is the fact that only the biotope of the forest interiors has all fruit-shapes at the locality. However, these sites do not represent the natural oak forests; they are usually semi-ruderal forests often consisting of pioneer woody species (like Prunus avium, Prunus spinosa, Fraxinus excelsior and Acer platanoides). The character of such populations indicates spontaneous dispersion (especially by birds) from occurrences in an agricultural landscape.

The contrasting pattern offers a distribution of fruit types at non-natural sites (orchards and vineyards). The most favourite fruit shape types for human use are the pyriform and conical, both providing seemingly larger fruits than previously mentioned types. Both fruit-shape phenotypes were documented with high frequency, notably in orchards and gardens, specifically conical fruit-shape phenotype in $37.1 \%$ and pyriform one in $32.7 \%$ of all documented individuals. Combining the fact about the character of sites (single trees or group of few trees in orchards or among fields) and high proportions of phenotypes selected by humans for use (nearly $70 \%$ ) at such localities, supports the hypothesis for anthropogenic origin. The limit of phenotype comparison is the fact that trees (especially when they are more than 100 years old) set seeds every 2-3 years only. Further, it is known that individual trees have some variation in fruit shape depending on their health conditions or on the weather in a particular year (Kausch-Blecken von Schmeling, 2000). Although there can be an error in our data due to the phenotypic plasticity of individuals, we documented strong patterns favouring human-selected phenotypes at the studied sites.

Previous studies in Slovakia showed a similar, human-influenced pattern in the distribution of human-preferred fruit shape types. Among 97 trees in six regions of Slovakia, the egg-shaped $(56.7 \%)$ and conical $(23.4 \%)$ fruits were the most frequent types. Historically, the fruits were selected and cultivated based on their size, colour, taste, maturation period, and their resistance against diseases (Kausch-Blecken von Schmeling, 2000; Nyári, 2010). Therefore, the biggest fruits occur in places with a long history of service tree cultivation such as in Southern and Central Italy, Central France, Central Germany and in 


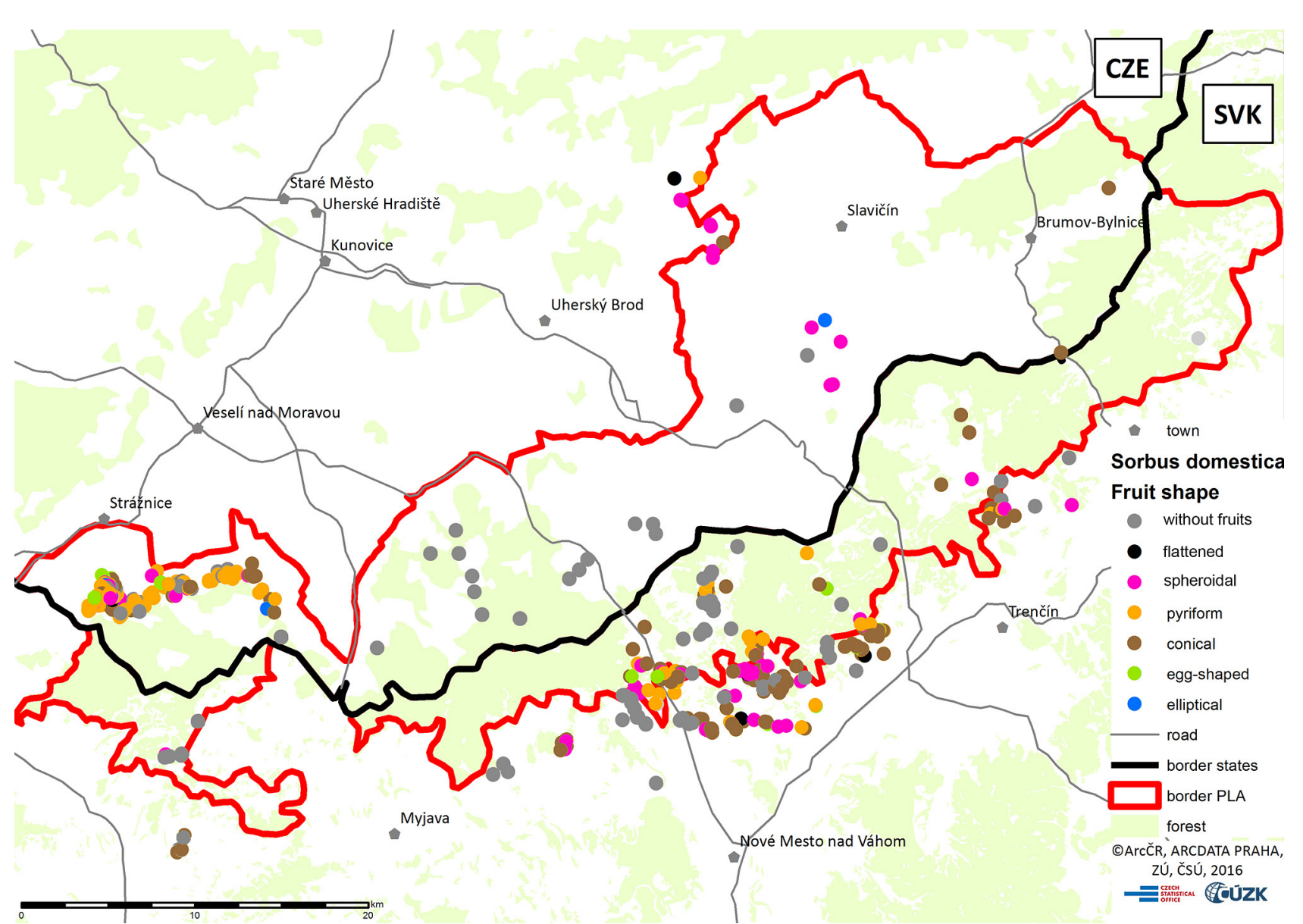

Fig. 8. Spatial distribution of the $S$. domestica individuals according to fruit shape

Crimea (Bignami \& Cammilli, 1998; Kausch-Blecken von Schmeling, 2000; Miko \& Gažo, 2004; Tetera et al., 2006, Benediková, 2009; Brindza et al., 2009).

We further analysed the $\mathrm{DBH}$ of individuals and their heights, which we found that there is a continued proportion between the DBH. Further, the DBH is continuously correlated among the biotopes. Only a weak (not significant) higher proportion of larger (putatively older) trees was documented for the agricultural landscape, not providing any strong evidence for their origin from the natural forest from periods before the agricultural use of the landscape. The proportion of the DBH and the height is not significantly obvious within the individuals growing in the forest interior because of their different strategy in the canopy, which forces them to be tall. We predict that the origin of these forest individuals is natural and is not affected by humans. The natural reproduction could be ensured by the large amount of fruits, and thus, the seeds, mainly during seed years. Steiner et al. (2009) observed higher rates of natural regeneration of $S$. domestica at particular sites in the Vienna Woods hills: clearcuttings (8 young plants per hectare) and on deer-free sites ( 6 plants/ha). The species is a light demanding plant and on sites with open canopy it successfully competes for light with other woody species. It has the optimum conditions for growth in the open land or scattered woodlands (as it is known from the Mediterranean populations) and these artificial clearcuttings help the young plants successfully overcome the insufficient condition in fragmented Central European oak forests. Although we did not study this factor in detail, it likely plays an important role at our sites too. Forest biotopes at studied localities represent rather closed forests (see example on Fig. 1) and not the natural oak forests with scattered distribution of trees.

The role of ruminants has to be considered as well, although we have not collected such data in the field. Generally speaking for whole Czechia, the cloven-hoofed game is alarmingly overpopulated in the region and causing damage to forests (see e.g. Annuals Reports on the Environment of the Czech Republic issued by the Ministry of the Environment of the Czech Republic; www.mzp.cz).

According to our research, most individuals in the White Carpathians grow on the western and southern orientation of the slopes, but trees that grow at a lower altitude do not have a preferential orientation of the slopes. The most significant is the human impact on planting. The higher the altitude, the bigger the probability of the trees occurrence in S-W or $S$ 
exposition. Generally, the service tree prefers slopes with plenty of sunlight facing west-, southwest-, south-, and south-eastward. Local differences in the species composition may, therefore, be primarily explained by human settlement (Jongepierová, 2008).

\section{Conclusions}

For this part of Europe, the occurrence of the species in the White Carpathians represents the northern distribution limit of the natural area of distribution (Kausch-Blecken von Schmeling Blecken, 2000; Enescu et al., 2016). The occurrence of the species here is scattered; however, it is relatively frequent compared with other regions of eastern Central Europe. Our data suggest that studied occurrences are most likely of anthropogenic origin. However, the largest populations (such as the Žerotín hill) can be dated to two centuries ago only as a result of the advent of vine cultivation in the region. Since the natural origin of $S$. domestica was continuously discussed and considered of an archaeophytic origin, it is not listed in the Red Lists of both Czechia and Slovakia (Grulich, 2012; Feráková et al., 2001). However, it is an important species from a cultural point of view. The long-time tradition of its use in cultivation, important landscape-mark tree, or its ornamental value (large, broadly branched tree) makes the species important for its conservation in nature. There is a documented decline in the species frequency in the White Carpathians since the $19^{\text {th }}$ century. It is due to intensive forest planting followed by the landscape damaging due to socialistic agricultural managements by field consolidation in the 50 s decade of the $20^{\text {th }}$ century (Hrdoušek et al., 2014; Jakubec et al., 2014). Recently, there is only limited regeneration of the surviving old trees (often having bad health conditions) in the regions. The younger individuals are usually planted in the gardens or orchards but are missing in the open landscape. The decline of the occurrence of species is a general problem documented in most European countries due to an overall reduction in the number of individuals, habitat fragmentation and isolation of populations, lack of natural regeneration, and disturbance of the natural metapopulation structure due to human impact (Young et al., 1996; Rotach, 2003; Enescu et al., 2016).

Sorbus domestica is a prospective fruit species with a high value for the landscape; thus, it is important to protect the populations of this species, even if they are not of natural origin. Cultivated individuals might represent interesting traits for future use as well as a reservoir of genetic variability of the highly fragmented population in Europe.

\section{Acknowledgements}

We thank all those who kindly helped with sampling or by valuable advice, particularly V. Hrdoušek (Tvarožná Lhota), M. Soviš (Hluk), and M. Duchoslav \& V. Pechanec (Palacký University in Olomouc). ZŠ was supported by the internal grant from Palacký University [IGA PrF-2016-001, IGA PrF-2017-001, IGA PrF-2018-001] and by the European Social Fund, Education for Competitiveness Operational Programme (CZ.1.07/2.2.00/28.0158). We also thank anonymous reviewers and the editor for helpful remarks on the previous version of the manuscript.

\section{References}

Aldasoro JJ, Aedo C, Garmendia FM, de la Hoz FP \& Navarro C (2004) Revision of Sorbus subgenera Aria and Torminaria (Rosaceae-Maloideae). Systematic Botany Monographs 69: 1-148.

Benediková M (2009) Metodické postupy množení a pěstování jeřábu oskeruše (Sorbus domestica L.). Recenzovaná metodika, Lesnický průvodce 3 . Výzkumný ústav lesního hospodářství a myslivosti, Strnady.

Bignami C \& Cammilli C (1998) Germoplasma di sorbo (Sorbus domestica L.) nel territorio del Alto Molise. Atti Del 4 Congresso Nazionale Sulla Biodiversità: Germoplasma Locale E Sua Valorizzazione, September 8-11, Sassary, Italy.

Brindza J, Červeňáková J, Tóth D, Bíro D \& Sajbidor $\mathrm{J}$ (2009) Unutilized potential of true service tree (Sorbus domestica L.). Acta Horticulturae 806: 717-725.

Brütsch U \& Rotach P (1993) Der Speierling (Sorbus domestica L.) in der Schweiz: verbreitung, ökologie, standsortsanspruche, konkurrenzkraft und waldbauliche eignung. Schweizerische Zeitschrift für Forstwesen 144: 967-991.

Campbell CS, Evans RC, Morgan DR, Dickinson TA \& Arsenault MP (2007) Phylogeny of subtribe Pyrinae (formerly the Maloideae, Rosaceae): limited resolution of a complex evolutionary history. Plant Systematics and Evolution 266: 119-145. doi:10.1007/s00606-007-0545-y.

Drvodelić D, Jemrić T \& Oršanić M (2015) Oskoruša: važnost, uporaba i uzgoj. University of Zagreb, Faculty of Forestry, Zagreb.

Enescu CM, de Rigo D, Houston Durrant T \& Caudullo G (2016) Sorbus domestica in Europe: distribution, habitat, usage and threats: European atlas of forest tree species (ed. by J San-Miguel-Ayanz, D de Rigo, G Caudullo, T Houston Durrant \& A Mauri) Publication Office of the European Union, Luxembourg. doi:10.2788/038466. 
Feráková V, Maglocký Š \& Marhold K (2001) Red list of ferns and flowering plants of Slovakia: Red list of plants and animals of Slovakia (ed. by D Baláž, K Marhold \& P Urban) Ochrana Prírody (suppl.) 20: 48-81.

George JP, Konrad H, Collin E, Thevenet J, Ballian D, Idzojtic M, Kamm U, Zhelev P \& Geburek T (2015) High molecular diversity in the true service tree (Sorbus domestica) despite rareness: data from Europe with special reference to the Austrian occurrence. Annals of Botany 115: 1105-1115. doi:10.1093/aob/mcv047.

Goldschmidt EE (2013) The evolution of fruit tree productivity: A review. Economic Botany 67: 5162. doi:10.1007/s12231-012-9219-y.

Grulich V (2012) Red list of vascular plants of the Czech Republic. Preslia 84: 631-645.

Harlan JR (1975) Our vanishing genetic resources. Science 188: 618-621.

Holuby JL (1888) Flora des Trencsiner Comitates. Fr. X. Skarnitzl, Trencsi.

Hrdoušek V, Špíšek Z, Krška B, Šedivá J \& Bakay L (2014) Oskeruše - strom pro novou Evropu. Petr Brázda Publishing, Hodonín.

Chytrý M, Kučera T, Kočí M, Grulich V \& Lustyk P (2010) Katalog biotopů České republiky. 2nd ed. Agentura ochrany přírody a krajiny ČR, Praha.

Jakubec $B$, Uherková $A$, Rajcová K, Ištvánová Z, Mertan V, Dovala O, Benediková D \& Stano D (2014) Bielokarpatský ovocný poklad. Záchrana starých a krajových odrôd ovocných drevín v regióne Bielych Karpát. Štátna ochrana prírody SR, Správa CHKO Biele Karpaty.

Janick J (2005) The origin of fruits, fruit growing and fruit breeding. Plant Breeding Reviews 25: 255-320.

Jongepierová I (2008) Louky Bílých Karpat, Grasslands of the White Carpathians Mountains. ZO ČSOP Bílé Karpaty, Veselí and Moravou.

Kaplan Z, Danihelka J, Lepší M, Lepší P, Ekrt L, Chrtek Jr. J, Kocián J, Prančl J, Kobrlová L, Hroneš M \& Šulc V (2016) Distributions of vascular plants in the Czech Republic. Part 3. Preslia 88: 459-544.

Kárpáti Z (1960) Die Sorbus-Arten Ungarns und der angrenzenden Gebiete. Feddes Repertorium 62: 71-331.

Kausch-Blecken von Schmeling W (2000) Der Speierling. Göttinger Tageblatt, Göttingen.

Květoň V \& Voženílek V (2011) Climatic regions of Czechia. Quitt's classification during years 19612000. Palacký University in Olomouc, Olomouc.

Lapin M, Faško P, Melo M, Štastný P \& Tomlain J (2002) Climate of the Slovak Republic: Landscape atlas of the Slovak Republic (ed. by L Miklos) Ministerstvo životného prostredia SR \& Slovenská agentúra životného prostredia, Bratislava \&
Banská Bystrica. https://geo.enviroportal.sk/atlassr/.

McAllister H (2005) The genus Sorbus: mountain ash and other rowans. Royal Botanic Gardens, Kew.

Mikic T, Orlovic S, Markovic M, Kovacevic B \& Pilipovic A (2008) Variability in service tree (Sorbus domestica L.) populations in Serbia. Forestry Journal 54: 61-67.

Miko M \& Gažo J (2004) Morphological and biological characteristics of fruits and seed of the service tree (Sorbus domestica L.). Journal of Fruit and Ornamental Plant Research 12: 139-146.

Miletić R \& Paunović MS (2012) Research into service tree (Sorbus domestica L.) population in eastern Serbia. Genetika 44: 483-490.

Moinet E (2009) Le traité du Cormier - Arbres remarquables. Histoire, usages, répartition dans la Sarthe, alentour et plus loin encore. SEPENES, La Ferte Bernard.

Nelson-Jones EB, Briggs D \& Smith AG (2002) The origin of intermediate species of the genus Sorbus. Theoretical and Applied Genetics 105: 953-963. doi:10.1007/s00122-002-0957-6.

Nikiforova SV, Cavalieri D, Velasco R \& Goremykin V (2013) Phylogenetic analysis of 47 chloroplast genomes clarifies the contribution of wild species to the domesticated apple maternal line. Molecular Biology and Evolution 30: 1751-1760. doi:10.1093/molbev/mst092.

Nyári L (2010) Genetic variability of service tree (Sorbus domestica L.) in the Hungarian middle mountains - based on cpDNA analysis in two regions. Acta Silvatica et Lignaria Hungarica 6: 17-32.

Pagan J \& Paganová V (2000) Service tree (Sorbus domestica L.) variation in Slovakia. Acta Facultatis Forestalis 42: 51-67.

Paganová V (2008) Ecology and distribution of service tree Sorbus domestica (L.) in Slovakia. Ekológia 27: 152-167.

Paganová V, Maceková M \& Bakay L (2015) A quantitative analysis of dendrometric data on Sorbus domestica L. phenotypes for urban greenery. Urban Forestry and Urban Greening 14: 599-606. doi:10.1016/j.ufug.2015.06.001.

Poljak I, Kajba D, Ljubić I \& Idžojtić M (2015) Morphological variability of leaves of Sorbus domestica L. in Croatia. Acta Societatis Botanicorum Poloniae 84: 249-259. doi:10.5586/asbp.2015.023.

Potter D, Eriksson T, Evans RC, Oh S, Smedmark JEE, Morgan DR, Kerr M, Robertson KR, Arsenault M, Dickinson TA \& Campbell CS (2007) Phylogeny and classification of Rosaceae. Plant Systematics and Evolution 266: 5-43. doi:10.1007/s00606007-0539-9. 
R Core Team (2015) R: A language and environment for statistical computing. R Foundation for Statistical Computing, Vienna.

Rapaics R (1940) A magyar gyümölcs. Királyi Magyar Természettudományi Társulat, Budapest.

Robertson KR, Phipps JB, Rohrer JR \& Smith PG (1991) A synopsis of genera in Maloideae (Rosaceae). Systematic Botany 6: 376-394. doi:10.2307/2419287.

Rotach P (2003) Technical guidelines of genetic conservation and use for service tree (Sorbus domestica). IPGR Institute, Rome.

Scheller H, Bauer U, Butterfass T, Fischer T, Grasmück H \& Rottmann H (1979) Der Speierling (Sorbus domestica L.) und seine Verbreitung im Frankfurter Raum. Mitteilungen der Deutschen Dendrologischen Gesellschaft 71: 5-65.

Steiner M (2009) Der Speierling in einem Forstrevier im südöstlichen Wienerwald. Austrian Journal of Forest Science 126: 133-173.

Termentzi A, Kefalas P \& Kokkalou E (2006) Antioxidant activities of various extracts and fractions of Sorbus domestica fruits at different maturity stages. Food Chemistry 98: 599-608. doi:10.1016/j.foodchem.2005.06.025.

Tetera V, Boček S, Jongepierová I, Krška B, Němec J, Pešek R, Řezníček V \& Tomčala L (2006) Ovoce Bílých Karpat. ZO ČSOP Bílé Karpaty. Veselí nad Moravou.

Tischler W (1965) Agrarökologie. VEB Gustav Fischer Verlag, Jena.

Tolasz R, Míková T, Valeriánová A \& Voženílek V (2007) Climate atlas of Czechia. Palacký University in Olomouc, Olomouc.

Úradníček L, Maděra P, Tichá S \& Koblížek J (2009) Dřeviny České republiky. Lesnická práce, Kostelec nad Černými lesy.

Végvári G (2000) Sorb apple (Sorbus domestica L.) selection in Hungary. Acta Horticulturae 538: 155158. doi:10.17660/ActaHortic.2000.538.24.
Velasco R, Zharkikh A, Affourtit J, Dhingra A, Cestaro A, Kalyanaraman A, Fontana P, Bhatnagar SK, Troggio M, Pruss D, Salvi S, Pindo M, Baldi P, Castelletti S, Cavaiuolo M, Coppola G, Costa F, Cova V, Dal Ri A, Goremykin V, Komjanc M, Longhi S, Magnago P, Malacarne G, Malnoy M, Micheletti D, Moretto M, Perazzolli M,Si-Ammour A, Vezzulli S, Zini E, Eldredge G, Fitzgerald LM, Gutin N, Lanchbury J, Macalma T, Mitchell JT, Reid J, Wardell B, Kodira Ch, Chen Z, Desany B, Niazi F, Palmer M, Koepke T, Jiwan D, Schaeffer S, Krishnan V, Wu Ch, Chu VT, King ST, Vick J, Tao Q, Mraz A, Stormo A, Stormo K, Bogden R, Ederle D, Stella A, Vecchietti A, Kater MM, Masiero S, Lasserre P, Lespinasse Y, Allan AC, Bus V, Chagné D, Crowhurst RN, Gleave AP, Lavezzo E, Fawcett JA, Proost S, Rouzé P, Sterck L, Toppo S, Lazzari B, Hellens RP, Durel Ch-E, Gutin A, Bumgarner RE, Gardiner SE, Skolnick M, Egholm M, Van de Peer Y, Salamini F \& Viola R (2010) The genome of the domesticated apple (Malus $\times$ domestica Borkh.). Nature Genetics 42: 833-839. doi:10.1038/ng.654.

Venables WN \& Ripley BD (2002) Modern applied statistics with S. Springer, New York.

Warburg EF \& Kárpáti ZE (1968) 28. Sorbus L.: Flora Europaea. Volume 2: Rosaceae to Umbelliferae (ed. by TG Tutin, VH Heywood, NA Burges, DM Moore, DH Valentine, SM Walters \& DA Webb) Cambridge University Press, Cambridge, pp. 6771.

Young A, Boyle T \& Brown T (1996) The population genetic consequences of habitat fragmentation for plants. Trends in Ecology and Evolution 11: 413418. doi:10.1016/0169-5347(96)10045-8.

Zohary D \& Spiegel-Roy P (1975) Beginnings of fruit growing in the Old World. Science 187: 319-327. doi:10.1126/science.187.4174.319. 